\title{
PERANCANGAN VIRTUAL MUSEUM BERBASIS CLIENT-SERVER DENGAN MENGGUNAKAN METODE USER CENTER DESIGN
}

\author{
Bagus M Akbar \\ Program Studi Informatika, Fakultas Teknik Industri, Universitas Pembangunan Nasional Veteran Yogyakarta, \\ Jl. SWK 104 (Lingkar Utara) Condong Catur, D I Yogyakarta, Indonesia, 55283 \\ e-mail: bagusmuhammadakbar@upnyk.ac.id
}

(Naskah masuk: 17 November 2020, diterima untuk diterbitkan: 25 Desember 2020)

\begin{abstract}
Abstrak
Perkembangan teknologi informasi membuat penggunaan teknologi menjadi sebuah kebutuhan bagi manusia. Kebutuhan pada teknologi juga datang dari dunia pendidikan dan wisata, salah satunya museum. Salah satu museum yang ada yaitu museum Geoteknologi Mineral UPN Veteran Yogyakarta. Seluruh aktivitas operasional pada museum tersebut masih dilakukan secara manual melalui informasi yang ditempel pada koleksi museum. Hal itu mengakibatkan pengunjung museum kesulitan untuk mengetahui informasi secara detail terkait koleksi museum karena beberapa informasi koleksi sudah rusak dan tersembunyi di balik kaca pengamanan koleksi museum. Untuk memudahkan pengunjung museum dalam mengakses informasi museum, pengelola museum menginginkan penggunaan teknologi untuk memudahkan pengunjung museum dalam melihat koleksi museum. Untuk memenuhi kebutuhan tersebut dilakukan perancangan aplikasi virtual museum ini dibuat berbasis client-server dan menggunakan QR Code. Perancangan aplikasi ini dilakukan dengan menggunakan metode User Center Design dalam model pengembangan sistem menggunakan model System Development Life Cycle (SDLC). Metode User Center Design adalah suatu metode pengembangan sistem informasi yang berfokus pada pengguna. Penggunaan metode user center design pada model system development life cycle dihasilkan beberapa tahapan proses pengembangan yaitu Identifikasi kebutuhan fungsional dan non fungsional, perancangan sistem dan jaringan, implementasi sistem dan pengujian sistem. Setelah dilakukan perancangan aplikasi virtual museum berbasis client-server dengan menggunakan metode user center design dan setelah dilakukan pengujian sistem dengan menggunakan metode black box testing didapatkan hasil sistem yang berfungsi dengan baik serta dapat memenuhi kebutuhan pengguna yang diidentifikasi dengan kebutuhan fungsional dan kebutuhan non fungsional.
\end{abstract}

Kata Kunci: Virtual Museum, User Center Design, System Development Life Cycle

\section{DESIGN OF CLIENT-SERVER BASED VIRTUAL MUSEUM APPLICATION USING USER CENTERED DESIGN METHOD}

\begin{abstract}
Information technology is making technology a necessity for humans. The need for technology also comes from the world of education and tourism, one of which is museums. One of the existing museums is the UPN Veteran Yogyakarta Mineral Geotechnology Museum. All operational activities at the museum are still carried out manually through information attached to the museum's collection. This makes it difficult for museum visitors to find detailed information regarding the museum collection because some of the collection information has been damaged and is hidden behind the museum collection's security glass. To make it easier for museum visitors to access museum information, museum managers want the use of technology to make it easier for museum visitors to view museum collections. To meet this need, a virtual museum application was designed to be made based on client-server and using QR Code.. The design of this application is carried out using the User Center Design method in a system development model using the System Development Life Cycle (SDLC) model. The User Center Design method is a user-focused information system development method. The use of the user center design method in the system development life cycle model resulted in several stages of the development process, namely identification of functional and nonfunctional requirements, system and network design, system implementation and system testing. After designing a client-server based virtual museum application using the user center design method and after testing the system using the black box testing method, the results of the system are functioning properly and can meet user needs identified with functional and non-functional needs.
\end{abstract}

Keywords: Virtual Museum, User Center Design, System Development Life Cycle 


\section{PENDAHULUAN}

Perkembangan teknologi informasi mengakibatkan perubahan proses kerja pada berbagai kegiatan dan sektor kehidupan termasuk bidang pendidikan dan pariwisata, salah satu bidang wisata edukasi adalah museum. Salah satu museum yang ada di provinsi Daerah Istimewa Yogyakarta adalah Museum Geoteknologi Mineral Universitas Pembangunan Nasional Veteran Yogyakarta yang memiliki koleksi mineral dan batuan yang ada di Indonesia. Sebagai bagian dari kegiatan pendidikan yaitu wisata edukasi, penerapan teknologi dalam bidang museum berguna untuk meningkatkan metode belajar siswa sehingga mampu mendapatkan hasil yang lebih optimal [1]

Untuk mendukung visi Museum Geoteknologi Mineral UPN menjadi museum yang modern dan bermutu internasional, dibutuhkan suatu pengelolaan museum yang modern dan mampu memudahkan pengunjung meangakes informasi koleksi museum yang ada. Akan tetapi, hal itu belum terwujud karena seluruh operasional museum masih dilakukan secara manual, mulai dari akses informasi, inventarisasi dan juga peminjaman koleksi museum. Hal tersebut menyebabkan pengunjung museum kesulitan untuk mengetahui dan mengakses informasi koleksi yang ada di museum Geoteknologi Mineral UPN.

Untuk menyelesaikan permasalahan tersebut diperlukan adopsi teknologi informasi untuk melakukan proses digitalisasi pada operasional museum [2]. Digitalisasi museum virtual pernah dilakukan oleh beberapa peneliti sebelumnya [11], [12], [13]. Untuk itu pada penelitian dilakukan dengan perancangan aplikasi Virtual Museum berbasis Client-Server dan QR Code pada Museum Geoteknologi Mineral UPN Veteran Yogyakarta yang dapat diakses oleh pengunjung menggunakan komputer touchscreen dan handphone miliknya. Dengan menggunakan konsep client-server, maka komputer server dapat memberikan layanan dan bertukar informasi pada komputer client [3]. Oleh karena itu, aplikasi ini diaharapkan dapat memudahkan pengelola museum untuk melakukan inventarisasi dan melakukan proses simpan pinjam koleksi museum. Pada penelitian ini juga memanfaatkan metode user center design sebagaimana pernah dilakukan oleh [14] pada museum arkeolog di italia. Sedangkan [15] merancang virtual museum pada batik.

\section{METODE PENELITIAN}

Metode Penelitian yang digunakan dalam perancangan virtual museum adalah metode User Center Design (UCD). UCD merupakan metode pendekatan yang dioptimalkan untuk berorientasi pada kebutuhan end user atau pengguna agar pengguna mendapatkan kepuasan dan hasil yang optimal tanpa mengubah kebiasaan wajarnya ketika menggunakan suatu tools atau produk.

UCD dibangun melalui proses interaktif dengan pengguna sejak ditetapkannya tujuan pembuatan produk hingga perancangannya kemudian dievaluasi dengan memperhatikan faktor user experience [4]. Dalam perancangan sistem virtual museum berikut dikembangkan metode User Centered Design yang dintegrasikan dengan metode pengembangan sistem informasi System Development Life Cycle (SDLC) yang merupakan salah satu metode pengembangan sistem [5]. Proses pengembangan perangkat lunak dibagi menjadi beberapa tahapan yang mengatur pekerjaan pengembangan produk perangkat lunak dibuat sesuai dengan fungsionalitas yang dibutuhkan dan sesuai dengan waktu dan anggaran yang direncanakan [6]. Untuk itu tahapan penelitian yang dilakukan dalam penelitian ini sebagai berikut:

1. Identifikasi kebutuhan fungsional dan nonfungsional, pada tahap ini peneliti mengidentifikasi kebutuhan pengguna yaitu pengelola museum yang dilakukan dengan cara wawancara dan mengidentifikasi kebutuhan pendukung dari sistem yang dikembangkan.

2. Perancangan Sistem, pada tahap ini peneliti melakukan perancangan sistem mulai dari membuat use case diagram, activity diagram, diagram alir data, desain relasional basis data dan juga rancangan jaringan yang digunakan

3. Implementasi Sistem, pada tahap ini dilakukan implementasi dari rancangan sistem yaitu sistem dibuat dengan berbasis website. Sistem ini dibuat dengan konsep client-server yang memungkinkan sharing data dan menghindari replikasi data [7]. Sistem ini dapat dijalankan dengan komputer touch screen dan menggunakan QR Code. Sistem dibuat dengan menggunakan bahasa pemrograman PHP dan basis data MySQL supaya dapat diakses oleh pengguna melalui jaringan komputer [8].

4. Pengujian Sistem, pengujian sistem dilakukan dengan metode black box testing untuk menguji fungsionalitas sistem yang dibuat.

Proses integrasi antara metode user centered design dan system development life cycle digambarkan pada gambar 1 .

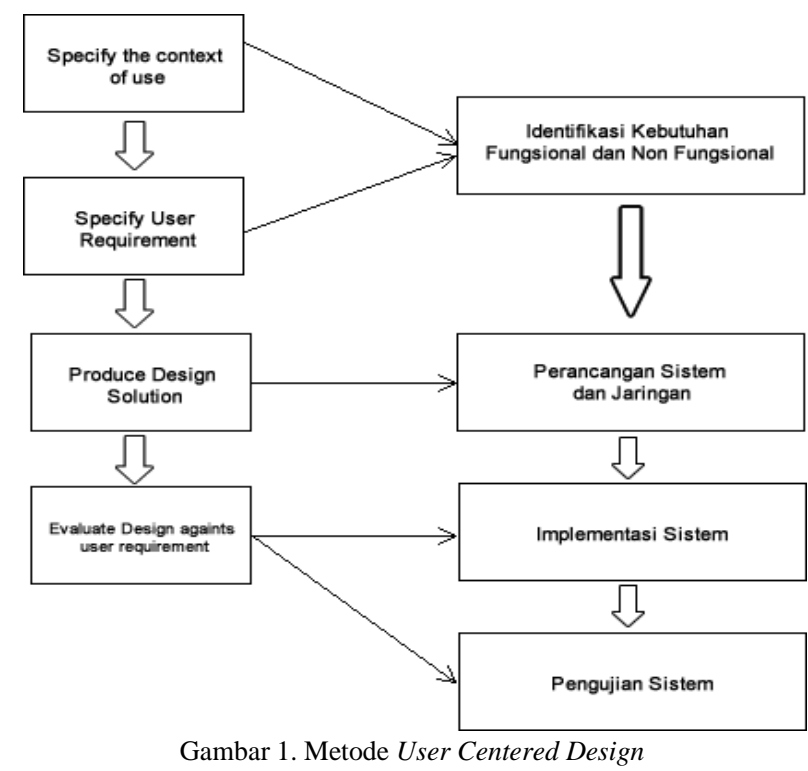




\section{PERANCANGAN SISTEM}

Perancangan aplikasi virtual museum ini dibuat beberapa diagram untuk menjelaskan alur kerja sistem dan interakasi antara sistem dan pengguna. Sistem ini dibangun berbasis client-server dengan 1 server dan terhubung dengan 5 buah client komputer layar sentuh (touchscreen). Penggunaan metode User Center Design pada perancangan suatu aplikasi dilakukan dalam beberapa tahapan yaitu:

\subsection{Identifikasi Kebutuhan}

Tahapan pertama dari perancangan sistem yaitu identifikasi kebutuhan dari pengguna yang terbagi dalam dua kebutuhan, yaitu:

1. Kebutuhan Fungsional

User yang terdapat dalam sistem virtual museum terbagi menjadi 2 pengguna yaitu pengunjung, dan pengelola/administrator. Dari hasil wawancara dan analisis yang dilakukan, kebutuhan untuk pengunjung museum adalah sebagai berikut:

- Pengunjung dapat melihat keterangan koleksi museum dengan mudah dan lengkap

- Pengunjung dapat melihat koleksi museum dengan menggunakan telepon pintar

Sedangkan untuk kebutuhan pengelola/admin yaitu:

- Pengelola museum dapat melakukan inventarisasi koleksi museum dengan mudah

- Pengelola museum dapat melakukan proses pengelolaan peminjaman koleksi museum dengan mudah

2. Kebutuhan Non Fungsional

Dalam perancangan sistem virtual museum ini dibutuhkan perangkat keras pendukung server dengan spesifikasi

- Komputer Core i3 dengan RAM 8 GB

- Digunakan pada sistem operasi Linux Ubuntu 12.04 dengan aplikasi Apache dan MySQL Server

- Memiliki daya simpan sistem 1 TB

- Terhubung dengan jaringan LAN atau WLAN

Untuk perangkat keras pendukung client memiliki spesifikasi teknis

- Digunakan pada sistem operasi Windows dengan spesifikasi minimal windows 7 dan dilengkapi browser mozilla firefox

- Spesifikasi komputer minimal Pentium IV dengan RAM 2 GB dan terhubung dengan jaringan LAN atau WLAN

\subsection{Perancangan Sistem}

Diagram pertama yang dibuat dalam perancangan sistem ini adalah Use Case Diagram untuk mendiskripsikan hubungan antara pengguna sistem dengan proses-proses yang ada pada sistem. Use Case dan Activity Diagram mampu memodelkan perilaku sistem [9]

.Use Case Diagram yang dibuat pada penelitian ini melibatkan 2 pengguna yaitu pengunjung dan admin. Sedangkan untuk proses yang terdapat pada sistem ini yaitu proses lihat koleksi, cari koleksi, input koleksi, input peminjaman, input pengembalian seperti pada Gambar 2.

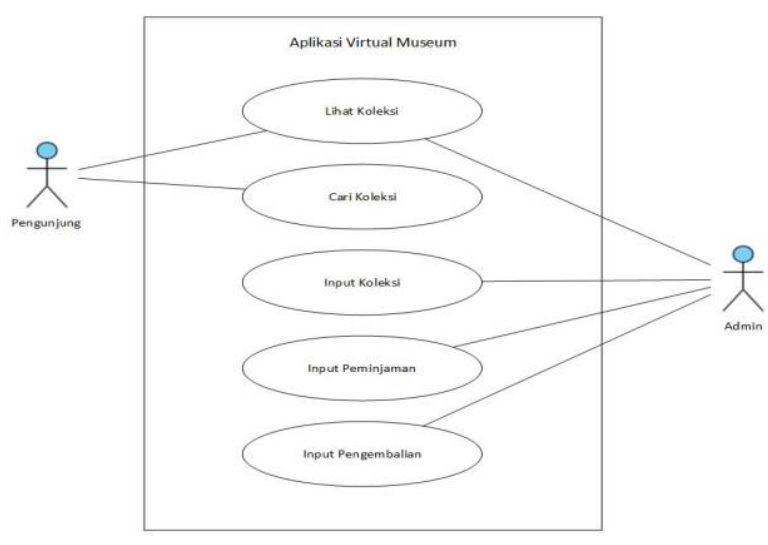

Gambar 2. Use Case Diagram Aplikasi Virtual Museum

Diagram yang digunakan untuk menjelaskan aktifitas yang ada pada tiap proses kerja menggunakan Activity Diagram. Aktifitas yang ada epada sistem dibagi menjadi 3 bagian yaitu aktifitas pengunjung, admin dan peminjam. Pada bagian aktifitas pengunjung dimulai dari pengunjung memilih kategori kemudian pengunjung memilih koleksi museum ataupun melakukan scan qr code pada label yang ada di dalam koleksi museum.

Selanjutnya, untuk aktifitas admin museum dimulai dengan login kemudian admin memilih input koleksi atau input peminjaman koleksi. Kemudian untuk aktifitas peminjam dimulai dari mengisi formulir peminjaman dilanjutkan dengan input pengembalian jika sudah habis waktu peminjaman. Diagram aktifitas tersebut terlihat pada gambar 3 . 


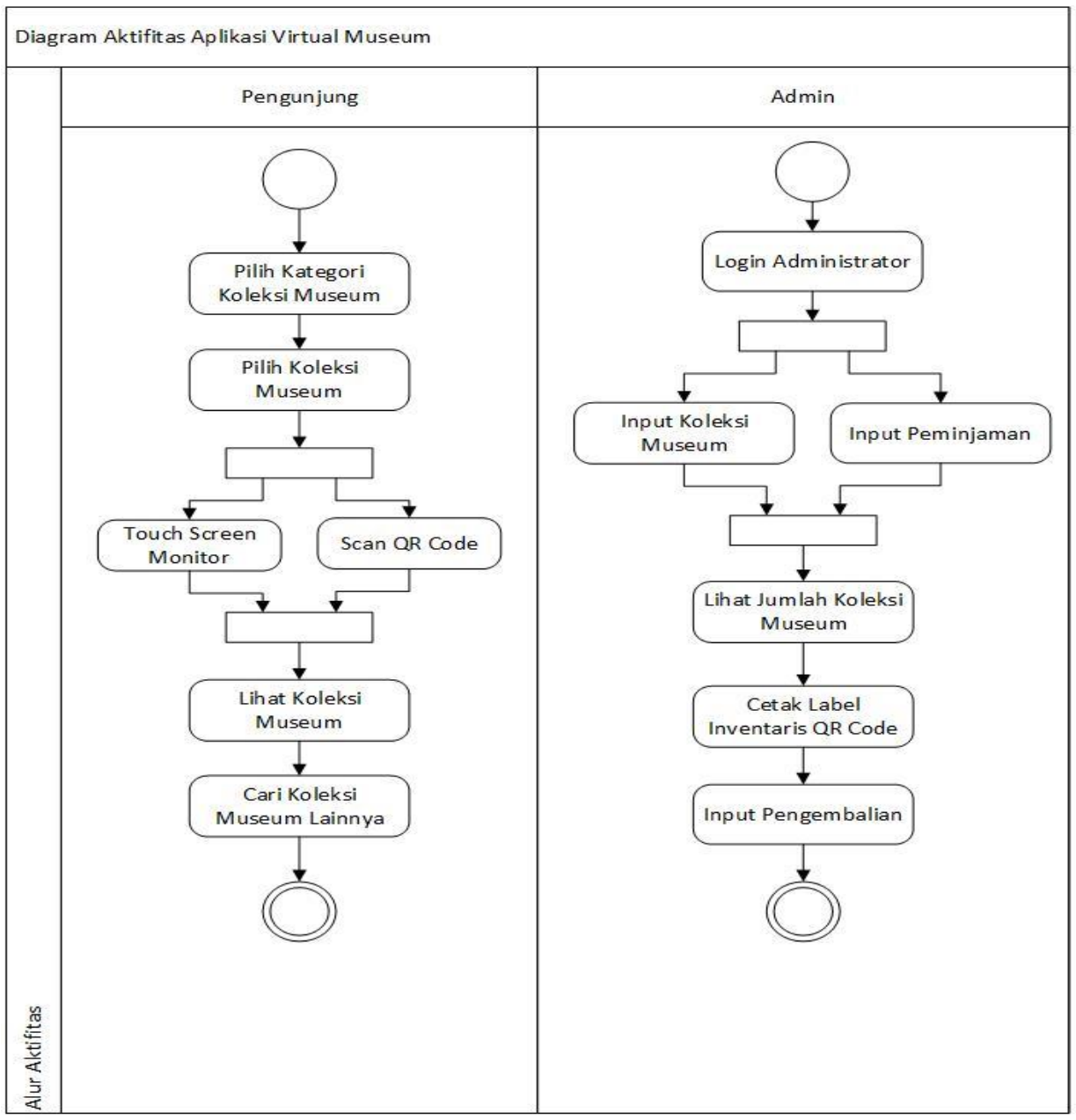

Gambar 3. Activity Diagram

Dalam perancangan sistem ini mempunyai diagram alir data yang menggambarkan alur pemrosesan data pada sistem ini. Dalam diagram alir data level 1 terdapat lima proses yaitu proses data kategori, proses data hibah, proses data koleksi, proses data peminjam dan proses data peminjaman. Sistem ini menggunakan basis data untuk penyimpanan data dengan 6 buah tabel yaitu tabel koleksi, tabel kategori, tabel hibah, tabel transaksi, tabel peminjam dan tabel user. Tabel koleksi yang digunakan untuk menyimpan data koleksi berelasi dengan tabel hibah, tabel kategori dan tabel transaksi sedangkan tabel transaksi yang digunakan untuk menyimpan data peminjaman berelasi dengan tabel peminjam.

\subsection{Perancangan Jaringan}

Untuk rancangan jaringan dari virtual museum yang dibangun menggunakan jaringan Local Area Network (LAN) dengan 1 server dan 5 client. Jaringan lokal yang dibuat pada sistem virtual museum dilengkapi dengan access point untuk koneksi ke telpon pintar pengguna menggunakan jaringan wireless yang dapat digunakan untuk scan kode QRCode yang terdapat pada label koleksi museum seperti yang terlihat pada gambar 4 .

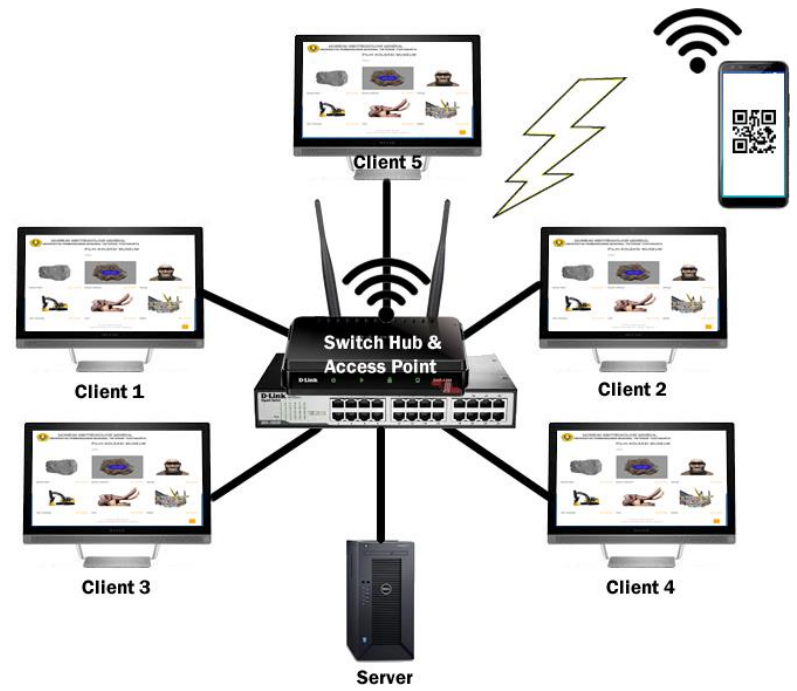

Gambar 4. Desain Jaringan Virtual Museum

\section{HASIL DAN PEMBAHASAN}

\subsection{Implementasi Sistem}

Implementasi sistem virtual museum dibuat untuk melayani tiga pengguna yaitu: pengunjung, pengelola museum dan institusi peminjam koleksi museum. 


\section{Menu Pengunjung}

Menu pengunjung pada aplikasi ini terdapat menu koleksi museum yang dapat digunakan untuk melihat informasi koleksi museum yang ditunjukan pada gambar 5 dan 6. Pada tampilan informasi koleksi berisi tentang kategori koleksi, jumlah koleksi, umur benda koleksi, asal benda koleksi dan pemberi benda koleksi.

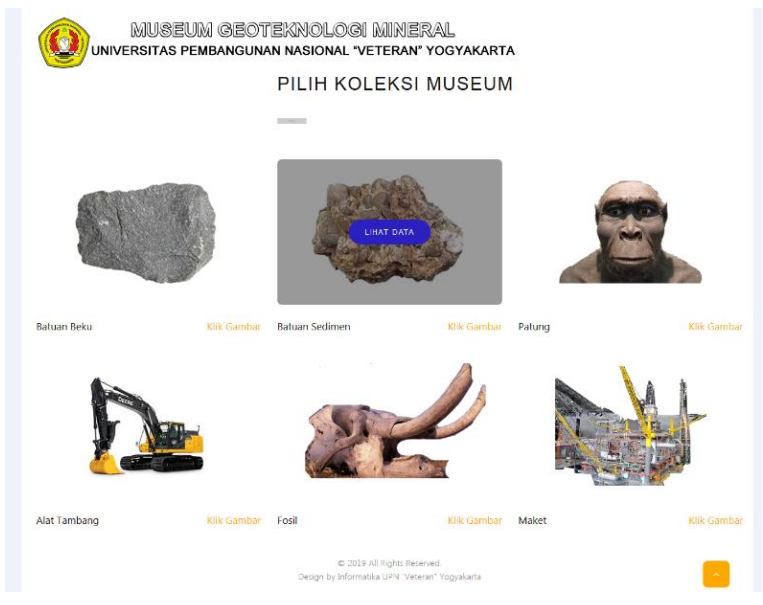

Gambar 5. Aplikasi Pengunjung
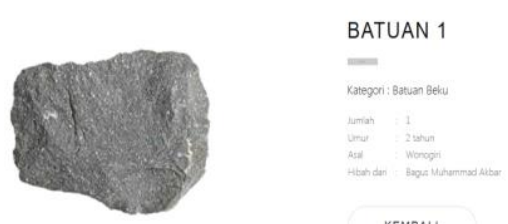

Gambar 6. Detail Informasi Koleksi Museum

Menu pengunjung juga terdapat label koleksi berbasis QR Code yang dapat diakses dengan menggunakan mobile phone untuk melihat informasi koleksi museum yang ditunjukan pada gambar 7 .

\begin{tabular}{|c|c|c|}
\hline 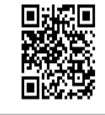 & 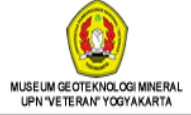 & $\begin{array}{ll}\text { Nomor Registrasi : } & 90886581 \\
\text { Nama Koleksi } & : \text { Batuan } 1 \\
\text { Umur } & : 2 \text { tahun }\end{array}$ \\
\hline
\end{tabular}

\section{Menu Administrator}

Gambar 7. Label Koleksi Museum

Menu login pada aplikasi ini digunakan untuk mengakses menu manajemen koleksi pada aplikasi virtual museum yang ada pada halaman adminstrator. Menu login pada aplikasi ini ditunjukan pada gambar 8 dan setelah administrator melakukan submit halaman login akan muncul tampilan beranda halaman admin yang dapat dilihat pada gambar 9 .

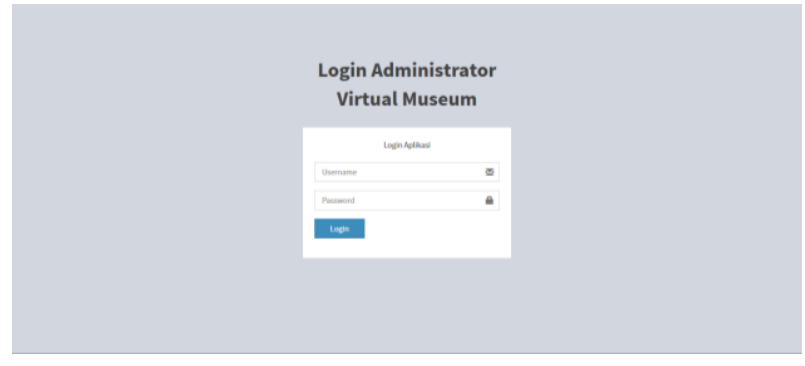

Gambar 8. Login Administrator

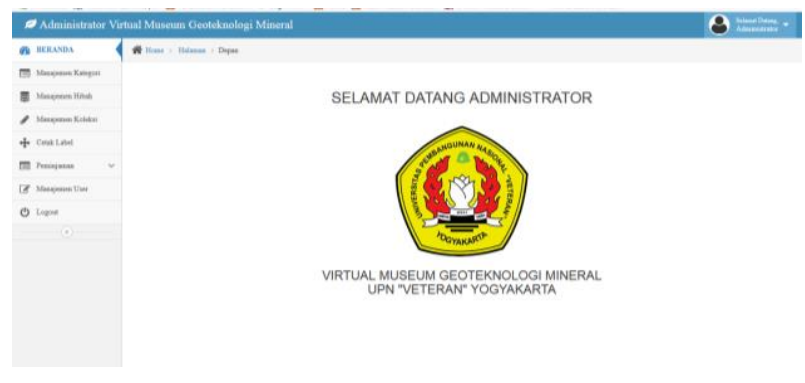

Gambar 9. Menu Beranda Admin

Menu administrator pada aplikasi ini terdapat menu manajemen koleksi yang digunakan untuk menambah dan mengubah data koleksi pada aplikasi virtual museum. Sebelum melakukan penambahan atau perubahan manajemen koleksi museum dilakukan penambahan kategori benda koleksi museum yang berisi tentang nama kategori dan gambar kategori dengan mengakes halaman menu manajamen kategori seperti pada gambar 10 .

Selanjutnya setelah melakukan penambahan kategori pada menu manajemen kategori dilakukan penambahan hibah yang digunakan untuk manajemen pemberian/hibah koleksi museum yang berisi tentang nama pemberi hibah, jenis kelamin pemberi hibah, alamat pemberi hibah, nomor telepon pemberi hibah, dan keterangan pemberi hibah dari instansi negara atau swasta seperti pada gambar 11 .

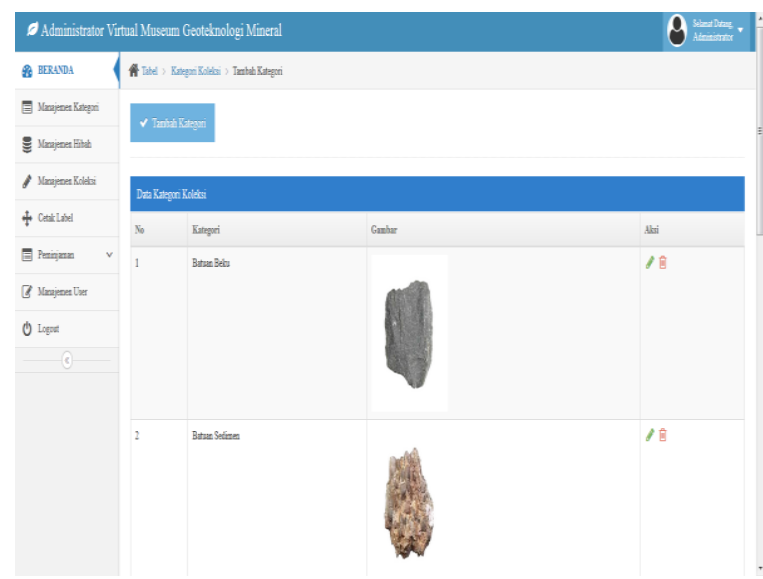

Gambar 10. Menu Manajemen Kategori 


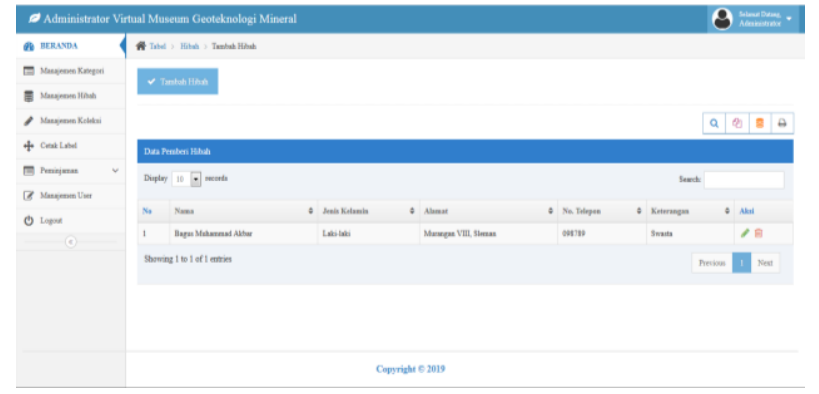

Gambar 11. Menu Manajemen Hibah

Kemudian untuk tampilan manajemen koleksi berisi tentang gambar koleksi, kategori koleksi, jumlah koleksi, dan pemberi hibah. Untuk tampilan menu koleksi terlihat pada gambar 12. Untuk mencetak informasi koleksi dalam bentuk label QR Code ditunjukan gambar 13.

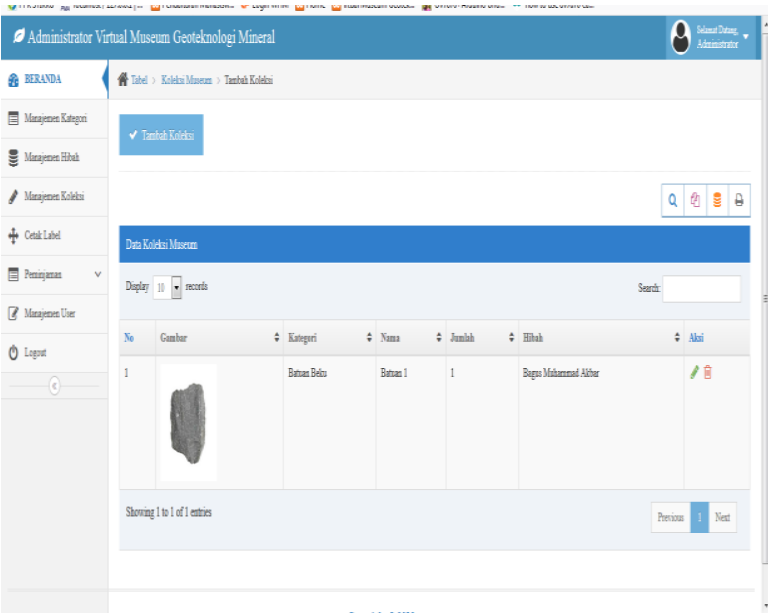

Gambar 12. Menu Manajemen Koleksi

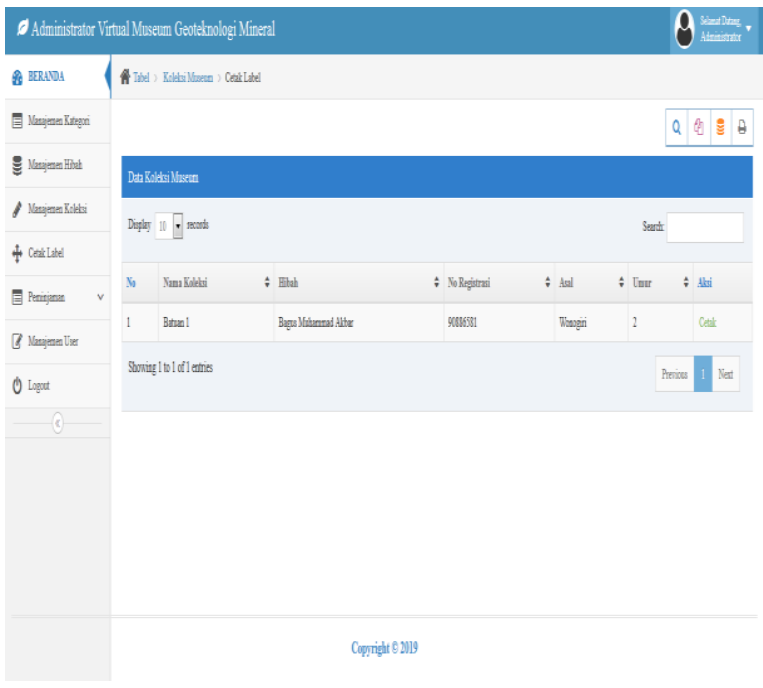

Gambar 13. Menu Cetak Label

Dalam menu administrator juga terdapat menu manajemen pengguna yang berisi tentang username pengguna, nama lengkap pengguna dan status pengguna yang ditunjukan pada gambar 14 .

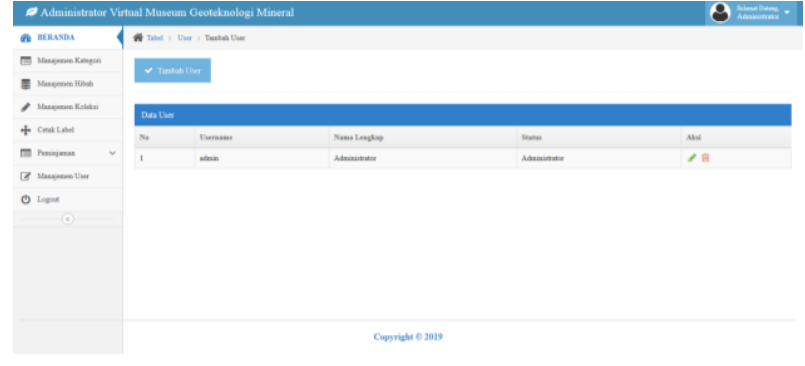

Gambar 14. Menu Manajemen Pengguna

Untuk melayani aktivitas peminjaman koleksi museum terdapat 2 menu yaitu menu peminjam yang digunakan untuk manajemen data peminjam yang berisi tentang nama peminjam, telepon peminjam, instansi peminjam, jabatan peminjam yang ditunjukkan pada gambar 15 .

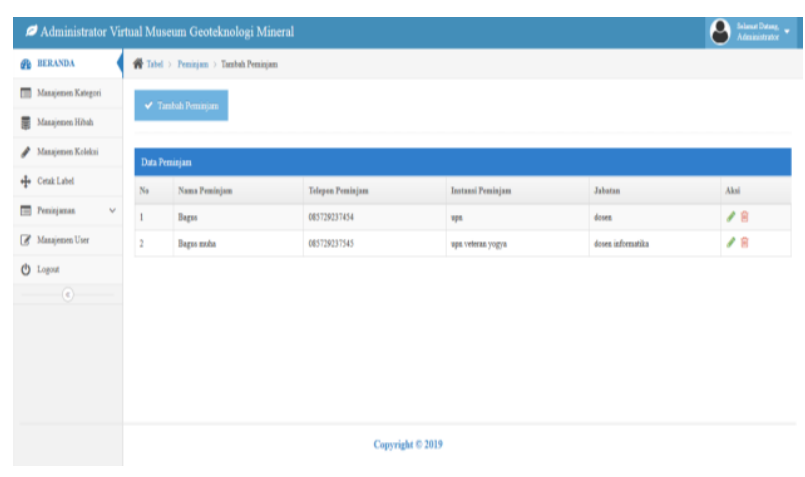

Gambar 15. Menu peminjam

Menu berikutnya dari aktifitas peminjaman kolesksi museum yaitu menu transaksi yang digunakan untuk manajemen data transaksi peminjaman benda koleksi museum yang berisi tentang nama peminjam koleksi, jumlah barang yang dipinjam, tanggal peminjaman, status pengembalian benda koleksi yang ditunjukkan pada gambar 16.

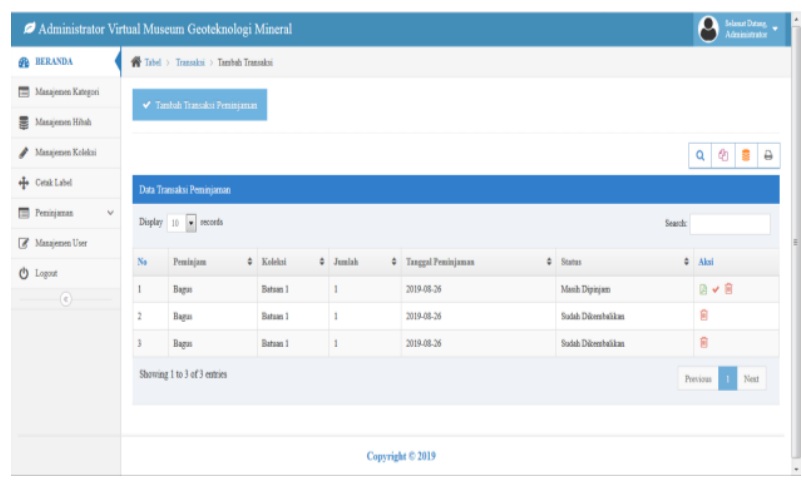

\subsection{Pengujian Sistem}

Pengujian pada sistem ini menggunakan metode pengujian black box testing. Dengan menggunakan pengujian black box testing mampu mengevaluasi kemampuan suatu aplikasi sehingga sesuai dengan spesifikasi yang diinginkan [10].

Pengujian aplikasi virtual museum ini dibagi berdasarkan klasifikasi pengguna yaitu pengujian 
halaman pengunjung dan pengujian halaman admin hasil pengujian menunjukkan semua sistem telah berjalan sesuai sebagaimana ditunjukkan pada Tabel 1 dan Tabel 2.

\begin{tabular}{|c|c|c|c|}
\hline No & $\begin{array}{l}\text { Proses yang } \\
\text { dilakukan }\end{array}$ & $\begin{array}{l}\text { Hasil yang } \\
\text { diharapkan }\end{array}$ & Keterangan \\
\hline 1 & $\begin{array}{l}\text { Klik Menu } \\
\text { "Koleksi”" }\end{array}$ & $\begin{array}{l}\text { Menampilkan } \\
\text { Keterangan } \\
\text { Koleksi } \\
\text { Museum }\end{array}$ & Valid \\
\hline 2 & $\begin{array}{l}\text { Klik Menu } \\
\text { "Pencarian" }\end{array}$ & $\begin{array}{l}\text { Menampilkan } \\
\text { Keterangan } \\
\text { Koleksi yang } \\
\text { dicari }\end{array}$ & Valid \\
\hline 3 & $\begin{array}{l}\text { Scan QR } \\
\text { Code } \\
\text { Koleksi }\end{array}$ & $\begin{array}{l}\text { Menampilkan } \\
\text { Keterangan } \\
\text { Koleksi } \\
\text { Museum } \\
\text { yang di scan } \\
\text { dengan kode } \\
\text { QR Code }\end{array}$ & Valid \\
\hline
\end{tabular}

\begin{tabular}{|c|c|c|c|}
\hline No & $\begin{array}{l}\text { Proses yang } \\
\text { dilakukan }\end{array}$ & $\begin{array}{l}\text { Hasil yang } \\
\text { diharapkan }\end{array}$ & Keterangan \\
\hline 1 & $\begin{array}{l}\text { Klik Menu } \\
\text { "Manajemen } \\
\text { Kategori" }\end{array}$ & $\begin{array}{l}\text { Menampilka } \\
\mathrm{n} \text { halaman } \\
\text { manajemen } \\
\text { kategori }\end{array}$ & Valid \\
\hline 2 & $\begin{array}{c}\text { Klik Menu } \\
\text { "Manajemen } \\
\text { Hibah" }\end{array}$ & $\begin{array}{l}\text { Menampilka } \\
\mathrm{n} \text { halaman } \\
\text { manajemen } \\
\text { hibah }\end{array}$ & Valid \\
\hline 3 & $\begin{array}{c}\text { Klik Menu } \\
\text { "Manajemen } \\
\text { Koleksi" }\end{array}$ & $\begin{array}{l}\text { Menampilka } \\
\mathrm{n} \text { halaman } \\
\text { manajemen } \\
\text { koleksi }\end{array}$ & Valid \\
\hline 4 & $\begin{array}{c}\text { Klik Menu } \\
\text { "Cetak } \\
\text { Label" }\end{array}$ & $\begin{array}{l}\text { Menampilka } \\
\mathrm{n} \text { halaman } \\
\text { cetak label }\end{array}$ & Valid \\
\hline 5 & $\begin{array}{l}\text { Klik Menu } \\
\text { Peminjaman }\end{array}$ & $\begin{array}{l}\text { Menampilka } \\
\mathrm{n} \text { halaman } \\
\text { peminjaman }\end{array}$ & Valid \\
\hline 6 & $\begin{array}{c}\text { Klik Menu } \\
\text { "Manajemen } \\
\text { User" }\end{array}$ & $\begin{array}{l}\text { Menampilka } \\
\mathrm{n} \text { halaman } \\
\text { manajemen } \\
\text { user }\end{array}$ & Valid \\
\hline
\end{tabular}

Keterangan: Valid merupakan ketika proses yang dilakukan menampilkan halaman yang sesuai dengan hasil yang diharapkan.

\section{Hasil Kuesioner Pengunjung Museum}

Setelah dilakukan prototyping pada aplikasi virtual museum ini dilakukan pembagian kuesioner pada pengunjung museum untuk mengukur kemudahan pengunjung dalam mengakses informasi koleksi museum. Kuesioner ini dibuat dalam skala likert 1-4 yang menunjukkan angka 1 yaitu sangat tidak setuju, angka 2 adalah tidak setuju, angka 3 adalah setuju, angka 4 adalah sangat setuju. Hasil yang didapat setelah dilakukan pembagian kuesioner pada pengunjung museum selama 1 bulan Adapun hasilnya ditunjukkan pada Tabel 3 .

Tabel 3. Hasil Kuesioner Pengalaman Pengunjung

\begin{tabular}{|c|c|c|c|c|c|}
\hline \multirow{2}{*}{ No } & \multirow{2}{*}{ Pertanyaan } & \multicolumn{4}{|c|}{ Hasil } \\
\hline & & 1 & 2 & 3 & 4 \\
\hline 1 & $\begin{array}{l}\text { Aplikasi virtual } \\
\text { museum mudah } \\
\text { digunakan }\end{array}$ & & & $46 \%$ & $56 \%$ \\
\hline 2 & $\begin{array}{l}\text { Aplikasi virtual } \\
\text { museum } \\
\text { membantu } \\
\text { mencari koleksi } \\
\text { museum yang } \\
\text { diinginkan }\end{array}$ & & & $49 \%$ & $51 \%$ \\
\hline 3 & $\begin{array}{l}\text { Aplikasi virtual } \\
\text { museum } \\
\text { memudahkan } \\
\text { dalam mengakses } \\
\text { informasi koleksi } \\
\text { museum }\end{array}$ & & & $49 \%$ & $51 \%$ \\
\hline
\end{tabular}

Berdasarkan pengujian pada seluruh menu yang terdapat pada sistem baik dari pengujian pada menu pengunjung maupun pengujian pada menu admin, didapatkan hasil bahwa secara fungsionalitas tidak terdapat kesalahan/eror. Kemudian setelah dilakukan survei dengan pembagian kuesioner pada pengunjung museum didapatkan hasil sebagian besar pengunjung merasa terbantu dan dimudahkan dalam mengakes informasi koleksi museum menggunakan aplikasi tersebut. Oleh karena itu, hasil yang diinginkan oleh pengguna sudah sesuai dengan yang diterapkan pada sistem.

\section{KESIMPULAN}

Penerapan metode user center design mampu menciptakan rancangan suatu aplikasi virtual musem yang sesuai dengan kebutuhan pengguna. Berdasarkan rancangan yang ada, Aplikasi virtual museum dibangun berbasis client-server dan menggunakan konsep touch screen serta $Q R$ Code. Berdasarkan pada pengujian sistem yang dilakukan menggunakan metode black box testing tidak didapatkan kesalahan/eror dan berdasarkan hasil kuesioner yang dibagikan pada pengunjung museum menunjukkan hasil yang baik. Oleh karena itu, aplikasi virtual museum ini dapat berjalan dengan baik dan sesuai dengan fungsionalitas sistem serta sesuai dengan kebutuhan pengguna. 


\section{DAFTAR PUSTAKA}

[1] I. El Khalkhali, 2014. "The use of DOKEOS elearning platform in a Moroccan Business School," Int. Conf. Multimed. Comput. Syst. Proceedings, pp. 633-638, doi: 10.1109/ICMCS.2014.6911146.

[2] L. A. Maye, D. Bouchard, G. Avram, and L. Ciolfi, 2017. "Supporting cultural heritage professionals adopting and shaping interactive technologies in museums," DIS 2017 - Proc. 2017 ACM Conf. Des. Interact. Syst., pp. 221-232, doi: 10.1145/3064663.3064753.

[3] M. E. Wu, S. Y. Chang, C. J. Lu, and H. M. Sun, 2014, "A communication-efficient private matching scheme in Client-Server model," Inf. Sci. (Ny)., vol. 275, pp. 348-359, doi: 10.1016/j.ins.2014.01.016.

[4] K. R. Devi, A. M. Sen, and K. Hemachandran, 2012. "A working Framework for the UserCentered Design Approach and a Survey of the available Methods," Ijsrp, vol. 2, no. 4, p. 8, [Online]. Available: http://www.ijsrp.org/research_paper_apr2012/rp 05.html.

[5] N. A. Febriyati, M. Y. Arnol, S. Informasi, P. Online, and B. W. Nugraha, 2020. "Perancangan Sistem Informasi Penjualan Online Berbasis Web Design Sales Information System Online Based On Web On Batik," vol. 3, no. 3, pp. 153-158, doi: $10.33387 /$ jiko.

[6] R. Ganpatrao Sabale, 2012."Comparative Study of Prototype Model For Software Engineering With System Development Life Cycle," IOSR J. Eng., vol. 02, no. 07, pp. 21-24, doi: 10.9790/3021-02722124.

[7] H. S. Oluwatosin, 2014 "Client-Server Model," IOSR J. Comput. Eng., vol. 16, no. 1, pp. 57-71, doi: 10.9790/0661-16195771.

[8] R. Parlika et al., 2020. "Implementation Of Mysql Access And Local Web Server Through The Internet Network Using Ngrok," vol. 3, no. 3, pp. 131-136, doi: 10.33387/jiko.

[9] J. Chanda, A. Kanjilal, S. Sengupta, and S. Bhattacharya, 2009. "Traceability of requirements and consistency verification of UML UseCase, activity and class diagram: A formal approach," Proc. Int. Conf. Methods Model. Comput. Sci. ICM2CSO9, doi: 10.1109/icm2cs.2009.5397941.

[10] M. Ehmer and F. Khan, 2012. "A Comparative Study of White Box, Black Box and Grey Box Testing Techniques," Int. J. Adv. Comput. Sci. Appl., vol. 3, no. 6, pp. 12-15, doi: 10.14569/ijacsa.2012.030603.

[11] T. Deuschel., T. Heuss and B. Humm, 2014."The Digital Online MuseumA new approach to experience virtual heritage," Proceedings of the 4th International Workshop on Semantic Digital
Archives, pp. 38-48.

[12] G. Varinlioglu dan B. Ozguc, 2012.“ Web-based Information System for Virtual Museum of Underwater Cultural Heritage in Turkey," SIGRAD pp. 204-208.

[13] K. Whiteside, G. Atkinson, M. Stump, G. Lawrence dan D. E.Tamir, 2015.“ Musing: A Mobile Client and Web ServerAugmented Reality Applicationfor Museum Visitors and Curators," International Journal on Advances in Telecommunication. vol 8 (1). pp. 9-24.

[14] L. Barbieri, M. Muzzupappa dan F. Bruno, 2018.“ User-centered design of a virtual reality exhibit for archaeological museums," International Journal on Interactive Design and Manufacturing (IJIDeM). vol 12 (4). pp. 1-11.

[15] Suliswaningsih., E. Utami dan A. Sunyoto, 2017.“ Perancangan Museum Batik Virtualmenggunakan Pendekatan MDA," Jurnal Telematika. vol 10 (2). pp. 151-165. 